\title{
By-products of palm oil extraction and refining
}

\author{
Yew-Ai TAN \\ Malaysian Palm Oil Board, 6, Persiaran Institusi, \\ Bandar Baru Bangi, 47000 Kajang, Selangor, \\ Malaysia \\ $<$ tan@mpob.gov.my>
}

Oil palm cultivation in Malaysia takes up a total land area of 3.87 million hectares and yielded 13.98 million tons of crude palm oil (CPO) and 1.64 million tons of crude palm kernel oil (CPKO) in 2004. In the same year, export earnings of oil palm products was an impressive $\$ 8.0$ billion derived mainly from the sale of palm oil, palm kernel oil, palm kernel cake, palm oleochemicals and other finished palm products. The Malaysian Palm Oil Board (MPOB) was established with the principal objective of promoting, developing and advancing the Malaysian palm oil industry. One of the major responsibilities of MPOB is to provide scientific and technological support through dissemination of information and transfer of technologies.

\section{MPOB Zero Waste Strategy}

Research activities at MPOB are aimed at maximizing productivity, improving production efficiency and quality, and increasing value creation by expanding the palm oil value chain. The goal is to promote a globally competitive and sustainable industry. One of the research strategies mapped out by MPOB is the Zero Waste Strategy which is structured to optimise the utilization of oil palm biomass such as empty fruit bunches (EFB), fronds and trunks for field mulching; and for use in commercial products such as pulp and paper and medium density fibreboard. The generation of by-products or co-products from the production of palm oil is unavoidable but these products need not be disposed as waste if they are utilized effectively. Research on utilisation of by-products also addresses the value-addition strategy of MPOB. Figure 1 shows the huge quantities of products and by-products from the Malaysian palm oil industry in 2004. The

Texte d'une conférence prononcée (par l'intermédiaire de Michel Parmentier) dans le cadre de la Journée de I'AFECG, sur les « Ingrédients bioactifs issus des huiles végétales et marines » du 10 octobre 2005, Paris.

\begin{abstract}
This paper outlines the utilisation of by-products resulting from the extraction and refining of palm oil. It summarises research by the Malaysian Palm Oil Board (MPOB) directed at producing zero waste from the palm oil industry. MPOB regards by-products of the palm oil industry not as waste but resources. It will be evident that by-products from the palm oil industry can be and have been used extensively and that the research carried out is relevant to both the milling and refining sectors.
\end{abstract}

Key words: palm oil, mills, refineries, by-products, MPOB, zero waste graph emphasises the huge potential and revenue obtainable from the use of these by-products as feed materials for the manufacture of new products.

\section{By-products management}

The increasing annual production of CPO by-product management. Being cognisant of the importance of protecting the environment from pollution, MPOB has introduced a number of innovative uses for both solid and aquelisted in table 1. In the extraction of palm oil, fresh fruit bunches enter the milling process as the raw/feed material and exit as (a) desired products - crude palm oil, palm kernels (b) product specific by-products - EFB, palm pressed fibres (PPF), shells and, (c) process specific by-products - aqueous waste, sediment clarification. Figure 2 is a simplified flow chart showing raw/feed materials, products and by-products entering and leaving a typical palm oil mill and refinery. posed problems in waste disposal and ous by-products produced by palm oil mills as

\section{Solid by-products}

Land application of agricultural by-products is considered the more environmentally friendly solution for using the nutrients in the by-products rather than by diverting these materials to landfills and water ways. Product specific by-products from the palm oil mill are characterised by its high proportion of organic materials. These range from solid products (biomass) such as EFP, PPF and shells composed mainly of lignin, cellulose, hemicelluloses and other carbonaceous material. Formerly, shells and PPF were used mainly as fuel for the boiler to generate steam and electricity for running the palm oil mill. EFBs were burnt in incinerators for bunch ash or used for mulching in oil palm estates. Currently however, biomass from the palm oil industry has wide applications in the production of fibre and particle boards [1,2], charcoal briquettes [3] and various cellulose materials [4-6].

PPF have an oil content of 5-7\%. Oil extracted from PPF is very high in carotene $(3500-5000$ ppm), tocols (2000-3000 ppm), sterols (4000-

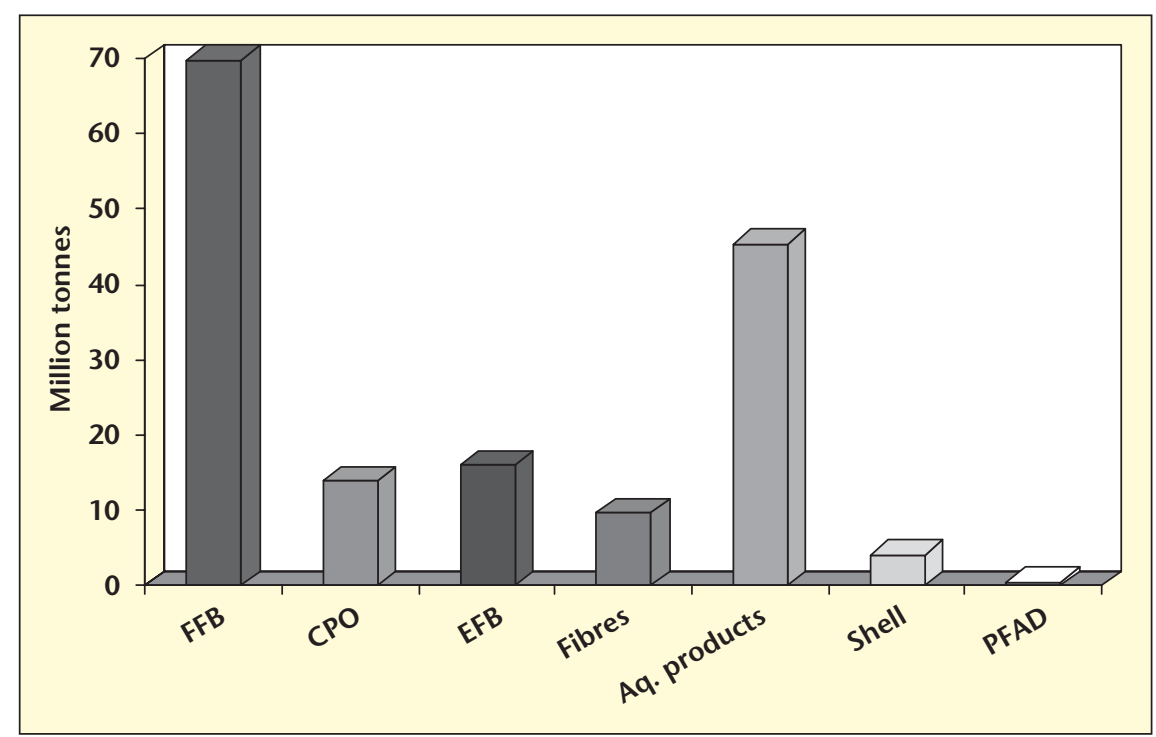

Figure 1. Malaysian production (2004) of crude palm oil and by-products from palm oil mills and refineries. 
Table 1. Utilisation of by-products from palm oil mills and refineries.

\begin{tabular}{|ll|}
\hline By-products & Use \\
\hline Aqueous by-products & Fertilisers \\
& Animal feed \\
& Phenolic antioxidants \\
\hline Empty fruit bunches (EFB) & Carboxymethylcellulose (CMC) \\
& Cellulose and lignin \\
& Fibre and Particle boards \\
\hline Palm pressed fibres (PPF) & De-oiled fibres \\
& Burnt as fuel \\
& Fibre composite \\
& Pulp and paper \\
& Adsorbents \\
& Incorporated in stone mastic asphalt \\
& Extractable carotenoids, vitamin E, squalene, phenolics, \\
& phospholipids and sterols from fibre oil for use in: \\
& Nutraceuticals \\
& Pharmaceuticals \\
& Cosmeceuticals \\
\hline Shells & Charcoal briquettes \\
\hline Palm fatty acid distillate (PFAD) & Squalene \\
& Phytosterols \\
& Tocopherols \\
& Tocotrienols \\
\hline
\end{tabular}

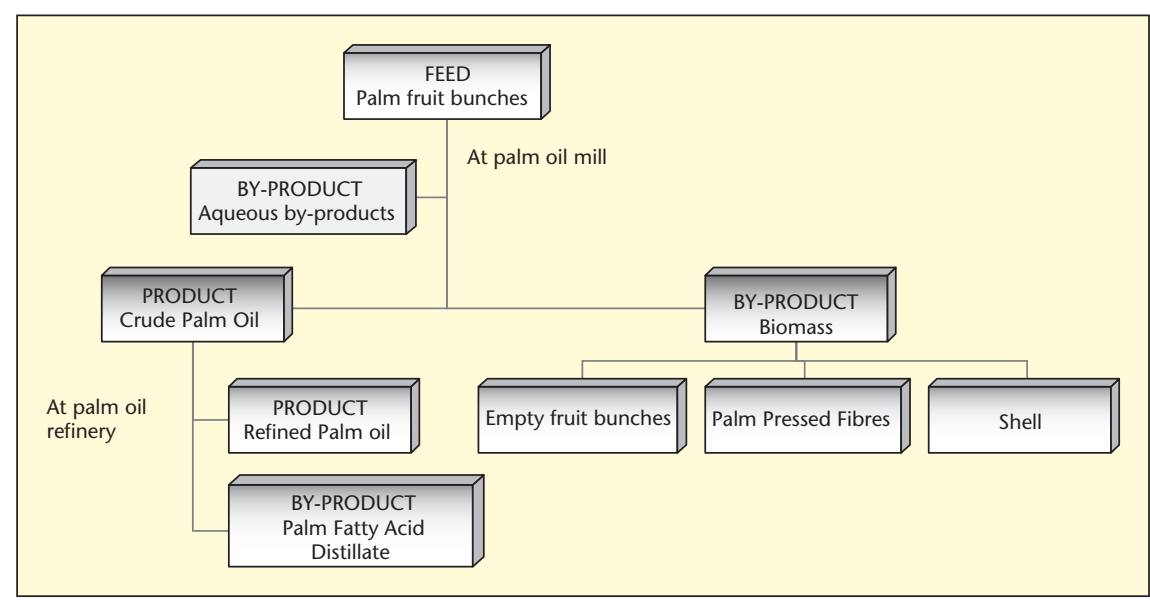

Figure 2. Products and by-products from palm oil milling and refining.

5000 ppm), phospholipids (6000 ppm), phenolics (1000-2000 ppm) and squalene (10001800 ppm) [7-9].

Research by MPOB scientists [9] showed that a single-step supercritical fluid extraction can be effectively used to recover residual oil from PPF. Separation techniques are then used to isolate valuable phytochemicals (table 1) from the oil. About $0.1-0.2 \%$ of phenolics can also be extracted from PPF using a combination of supercritical fluid extraction and separation techniques [10].

\section{Aqueous by-products}

Besides these solid by-products, palm oil mills also produce considerable amounts of aqueous waste. In the past, fine solids separated from aqueous waste were used as animal feed or fertilisers. Previously considered as low value, high volume aqueous by-products, palm oil mill effluent (POME) is now receiving attention as a source material for phenolic antioxidants. This aqueous waste has been shown to contain bioactive compounds such as phenolics antioxidants [11]. In recent years, research on palm phenolics has intensified in the light of the growing evidence of the health benefits of phenolic antioxidants. One of the most exciting technologies by MPOB is a patented process for the extraction of water-soluble antioxidants such as phenolic antioxidants from palm oil mill aqueous by-products. Presently, a 25\%$30 \%$ concentrate with potent antioxidant properties has been prepared and tested under IP protection. Tests have shown that the palm phenolics possess free radical scavenging activity similar to that of tea extracts. The high value palm extracts have applications in nutraceutical, pharmaceutical and cosmeceutical industries. Additionally, the abundance of aqueous by-products from the palm oil industry (figure 1) ensures a reliable, constant and natural source of supply for these industries.

\section{Refining by-products}

In 2004, Malaysian refineries produced 11.6 million tonnes of refined palm oil (RPO). Palm fatty acid distillate (PFAD) is a specific by-product produced during the step of deacidification-deodorisation of crude palm oil refining. Besides fatty acids, PFAD contains significant amounts of extractable tocopherols and tocotrienols $(0.2 \%)$, squalene $(0.6 \%)$ and phytosterols (table 1). Tocopherols and tocotrienols have been successfully extracted from esterified PFAD and subsequently concentrated using ion-exchange and distillation $[12,13]$. It was reported [14] that as much as 2205 tonnes of squalene could be sourced from PFAD in the year 2010. MPOB has a process for recovery of pure colourless squalene from PFAD [15]. Phytochemicals such as phytosterols $(0.6 \%)$ are entrained in PFAD and these can be isolated in a concentrated form for applications in nutraceuticals and functional foods [16]. The major palm phytosterols are the $\beta$-sitosterol, campesterol and stigmasterol.

Table 1 summarises the utilisation of main products and by-products. The table is not exhaustive because it only lists products from the extraction and refining of palm oil. Other by-products such as oil palm fronds and trunks, produced during replanting of palms, too have been effectively used in a number of products.

\section{Conclusion}

The Malaysian palm oil industry is expected to continue in its role as one of the major sources of revenue for the country. Although production of crude palm oil is projected to increase marginally in the coming years, new research findings on the use of the oil and the by-products generated from the industry are expected to raise export earnings. This optimistic view is reinforced by the current interest in biofuels. It is well known that palm oil is a 
cheap and abundant source for production of palm methyl esters (palm diesel) for use as biofuel. The sustained earning is also supported by the fact that many phytonutrients, including coenzyme Q10 [17], in palm oil can also be obtained from palm methyl esters by vacuum distillation, thereby making the production of biofuel from palm oil both an economical as well as a multi-product process.

\section{REFERENCES}

1. MOHAMAD H, ANIS M, RIDZUAN R, et al. MDF from oil palm biomass. MPOB Information Series, MPOB TT No. 168, 2002.

2. MOHAMAD $\mathrm{H}$, WAN HASAMUDDIN $\mathrm{H}$, ANIS M. Yap Ka Oil palm flat particleboard. MPOB Information Series, MPOB TT No. 208, 2003.

3. ROPAND M. Activated carbon production from palm oil palm waste and by-products. MPOB Information Series, MPOB TT No. 30, 1995.

4. ASTIMAR AA, MOHAMAD H, ANIS M, KAMARUDIN H, RIDZUAN R. Solvent-soda extraction of cellulose and lignin from oil palm biomass. MPOB Information Series, MPOB TT No. 170, 2002.

5. WAN HASAMUDIN WH, ROSNAH MS. Roadmaking using oil palm fibre (bits). MPOB Information Series, MPOB TT No. 171, 2002.
6. ROSNAH MS. GAPOR MT, WAN HASAMUDIN WH. Production of carboxymethylcellulose (CMC) from oil palm empty fruit bunch (EFB). MPOB Information Series, MPOB TT No. 228, 2004.

7. CHOO YM, YAP SC, OOI CK, et al. Recovered oil from palm-pressed fibre: a good source of natural carotenoids, vitamin $\mathrm{E}$ and sterols. / Am Oil Chem Soc 1996; 73(5).

8. CHOO YM, LAU HLN, PUAH CW, NG MH, BONG SC, MA AN, YUSO B. Production of phytonutrients (carotenes, vitamin $\mathrm{E}$, sterols, squalene, co-enzyme $\mathrm{Q}$ and phospholipids) from palm methyl esters. MPOB Information Series, MPOB TT No. 151, 2002.

9. CHOO YM, LAU HLN, NG MH, MA AN, YUSOF $B$. Value-added products from palm-pressed fibre. MPOB Information Series, MPOB TT No. 193, 2003.

10. LAU HLN, CHOO YM, MA AN, CHUAH CH. Identification of water-soluble compounds in palm-pressed mesocarp fibre by CC-MS and its antioxidant activity. Poster paper presented at the PIPOC 2005 - MPOB International Palm oil Congress, 25-29 September 2005, Petaling Jaya, Selangor, Malaysia, 2005.
11. RAVIGADEVI S, TAN YA, KALYANA S. Novel process for the production of water-soluble antioxidants with potential nutraceutical applications from palm oil mill effluent (POME). MPOB Information Series, MPOB TT No. 97, 2001.

12. GAPOR MT, LEONG WL, ONG ASH, KAWADA T, WATANABE H, TSUCHIYA N. Production of high concentration tocopherols and tocotrienols from palm oil by-products. USP 5190 618, US Patent and Trademark Office, 1993.

13. GAPOR MT. Production of palm based tocotrienols-enhanced fraction (TEF). MPOB Information Series, MPOB TT No. 290, 2005.

14. GAPOR MT, HAZRINA AR. Squalene in oils and fats. Palm Oil Developments 2000; 32: 36-40; (Malaysian Palm Oil Board).

15. GAPOR AB. MOHAMAD S, ROSNAH MS, HAZRINA AR. Process for recovery of squalene from palm oil products. MPOB Information Series, МРОВ TT No. 172, 2002.

16. $G A P O R A B$. Production of phytosterols from palm fatty acid distillate. MPOB Information Series, MPOB TT No. 173, 2002.

17. CHOO YM, NG MH, MA AH, YUSOF B. Production of coenzyme-Q10 from crude palm oil. MPOB Information Series, MPOB TT No. 232, 2004. 